\title{
Continuous infusion of glucose with model assessment: measurement of insulin resistance and $\beta$-cell function in man
}

\author{
J.P. Hosker, D. R. Matthews, A. S. Rudenski, M.A. Burnett, P. Darling, E. G. Bown and R. C. Turner \\ Diabetes Research Laboratories, Radcliffe Infirmary, Oxford, UK
}

\begin{abstract}
Summary. Continuous infusion of glucose with model assessment (CIGMA) is a new method of assessing glucose tolerance, insulin resistance and $\beta$-cell function. It consists of a continuous glucose infusion $5 \mathrm{mg}$ glucose $/ \mathrm{kg}$ ideal body weight per min for $60 \mathrm{~min}$, with measurement of plasma glucose and insulin concentrations. These are similar to postprandial levels, change slowly, and depend on the dynamic interaction between the insulin produced and its effect on glucose turnover. The concentrations can be interpreted using a mathematical model of glucose and insulin homeostasis to assess insulin resistance and $\beta$-cell function. In 23 subjects (12 normal and 11 with Type 2 (non-insulin-dependent diabetes) the insulin resistance measured by CIGMA correlated with that measured independently by euglycaemic clamp $\left(\mathbf{R}_{\mathrm{s}}=0.87, p<0.0001\right)$. With normal insulin resistance defined
\end{abstract}

as 1 , the median resistance in normal subjects was 1.35 by CIGMA and 1.39 by clamp, and in diabetic patients 4.0 by CIGMA and 3.96 by clamp. In 21 subjects (10 normal and 11 Type 2 diabetic) the $\beta$-cell function measured by CIGMA correlated with steady-state plasma insulin levels during hyperglycaemic clamp at $10 \mathrm{mmol} / 1\left(\mathrm{R}_{\mathrm{s}}=0.64, p<0.002\right)$. The CIGMA coefficient of variability was $21 \%$ for resistance and $19 \%$ for $\beta$-cell function. CIGMA is a simple, non-labour-intensive method for assessing insulin resistance and $\beta$-cell function in normal and Type 2 diabetic subjects who do not have glycosuria during the test.

Key words: Insulin resistance, $\beta$-cell function, mathematical model, glucose infusion, Type 2 diabetes, plasma insulin, plasma glucose.
Patients with Type 2 diabetes are usually characterised by the severity of their hyperglycaemia, as assessed by glucose tolerance tests or by fasting plasma glucose measurements. The methods available for assessing the extent to which both $\beta$-cell function and insulin resistance contribute to this hyperglycaemia are not suitable for routine use, and in most diabetic subjects pathophysiology is not assessed. If insulin resistance and deficient $\beta$-cell function could be readily differentiated, it might be possible to predict an individual patient's response to diet, sulphonylurea or insulin therapy.

The feed-back loop between the glucose stimulation of $\beta$-cell secretion and insulin regulation of glucose turnover in the liver, muscle and fat, plays a major rôle in the regulation of fuel supply [1]. Although this is basically a very simple homeostatic system, the interactions are sufficiently complex that the glucose and insulin responses to clinical tests are not easy to assess. Thus, interpretations of the rôles of insulin resistance and $\beta$-cell deficiency in maturity-onset diabetic subjects vary $[2,3]$. With the aid of mathematical models, the effects of different combinations of insulin resistance and $\beta$-cell deficiency can be predicted $[4,5]$.
We have investigated a new method which aims to give a near-physiological stimulus and to interpret the endogenous insulin and glucose responses. A standard, constant, low-dose glucose infusion is given for $60 \mathrm{~min}$. After $30 \mathrm{~min}$ the concentrations of insulin and glucose change slowly, and can be compared with reference values obtained from a computer-solved model of insulin/ glucose interaction, assuming different degrees of insulin resistance and $\beta$-cell deficit. This method we call

Table 1. Variables of computer model

\begin{tabular}{lll}
\hline Variables & $\begin{array}{l}\text { Basal steady-state } \\
\text { values for a normal } \\
70-\mathrm{kg} \text { man }\end{array}$ \\
\hline $\mathrm{G}$ & Plasma glucose concentration & $4 \mathrm{mmol} / 1$ \\
$\mathrm{I}$ & Plasma insulin concentration & $5 \mathrm{mU} / 1$ \\
$\mathrm{I}$ & 'Effective' insulin 'concentration' & $5 \mathrm{mU} / \mathrm{I}$ \\
$\mathrm{G}_{\mathrm{L}}$ & Hepatic glucose production rate & $0.82 \mathrm{mmol} / \mathrm{min}$ \\
$\mathrm{G}_{\mathrm{B}}$ & Cerebral glucose uptake rate & $0.42 \mathrm{mmol} / \mathrm{min}$ \\
$\mathrm{G}_{\mathrm{M}}$ & Muscle-fat glucose uptake rate & $0.4 \mathrm{mmol} / \mathrm{min}$ \\
$\mathrm{IDR}$ & Post hepatic insulin delivery rate & $11.3 \mathrm{mU} / \mathrm{min}$ \\
$\mathrm{V}_{\mathrm{G}} \quad$ Glucose space & 151 \\
$\mathrm{~V}_{\mathrm{I}} \quad$ Insulin space & 131 \\
$\mathrm{~B}$ & $\beta$-cell efficiency factor & 1.0 \\
$\mathrm{R}$ & Resistance factor & 1.0 \\
\hline
\end{tabular}


"continuous infusion of glucose with model assessment" (CIGMA).

In order to examine whether CIGMA would be a useful method for examining insulin resistance and $\beta$ cell function, we compared CIGMA's prediction for insulin resistance with estimates derived from (a) the euglycaemic hyperinsulinaemic clamp [6], (b) the hyperglycaemic clamp [6], (c) percentage ideal body weight [7], and (d) fasting plasma insulin concentrations. Similarly, we compared CIGMA's prediction for $\beta$-cell function with values derived from (a) the hyperglycaemic clamp and (b) the intravenous glucose tolerance test.

\section{Methods}

\section{The model}

Derivation of computer model. The model $[5,8]$ is based on available physiological data, with the aim of describing quantitatively the relationships between glucose and insulin. The functions used are drawn from experimental physiological data and therefore do not have simple mathematical formulations. Because of this, the equations below are descriptions rather than exact definitions of inter-relationships. The response-curve formats have been published $[5,8]$. The variables are summarised in Table 1.

A single compartment $\left(V_{G}\right)$ of distribution for glucose is used with separate turnover for brain $\left(\mathrm{G}_{\mathrm{B}}\right)$, liver $\left(\mathrm{G}_{\mathrm{L}}\right)$, and insulin-sensitive periphery including muscle and fat $\left(G_{M}\right)$. Glucose concentration $(G)$ changes as glucose is added by the liver or infusion and taken up by the periphery and brain:

$$
\frac{\mathrm{dG}}{\mathrm{dt}}=\frac{\mathrm{G}_{\mathrm{L}}-\mathrm{G}_{\mathrm{B}}-\mathrm{G}_{\mathrm{M}}}{\mathrm{V}_{\mathrm{G}}}
$$

Brain glucose uptake depends only on glucose concentration and, except at low glucose concentrations, hardly changes from its basal value of $0.42 \mathrm{mmol} / \mathrm{min}[9]$ :

$G_{B}=f_{B}(G)$ where $\frac{d f_{B}}{d G}>0$

(The term $f_{B}(G)$ is the function relating brain glucose uptake to the variable $\mathrm{G})$.

Muscle glucose uptake increases as glucose and 'effective' insulin concentrations $\left(I_{e}\right)$ rise [10-12], and decreases as insulin resistance $(R)$ increases:

$G_{M}=f_{M}\left(G\right.$, Ie, R) where $\frac{\partial f}{\partial G} M>0 \frac{\partial f}{\partial l e} M>0 \frac{\partial f}{\partial R} M<0$

Liver production of glucose, which is negative when there is net hepatic uptake, decreases as glucose and 'effective' insulin concentrations rise, and increases as resistance increases [13-15]. The concentration of insulin to which the liver is exposed is higher than that to which other tissues are exposed, but it is assumed that there is a constant relationship between the two such that increases in pre-hepatic insulin concentration are reflected by increases in post-hepatic insulin concentration. The liver glucose production function is represented thus:

$G_{L}=f_{L}(G, I e, R)$ where $\frac{\partial f_{L}}{\partial G}<0 \frac{\partial f_{L}}{\partial I e}<0 \frac{\partial f_{L}}{\partial R}>0$

For the purposes of the model, insulin is physically distributed in one compartment $\left(\mathrm{V}_{\mathrm{I}}\right)$ at plasma concentration (I), and first order disappearance kinetics are assumed. Any effects of insulin, however, are dependent on the 'effective' insulin 'concentration' in a remote 'effector compartment', which represents the amount of insulin being effective through processes, such as binding to receptors, internalization and enzyme activation.
Insulin is produced by the pancreas and taken up to a significant extent in its first pass through the liver [16]. The model is based on the post-hepatic insulin delivery rate (IDR) with a 4 min half-life for the exponential disappearance of insulin [17]:

$\frac{\mathrm{dI}}{\mathrm{dt}}=\frac{\text { IDR }}{\mathrm{V}_{\mathrm{I}}}-\mathrm{kI}$ where $\mathrm{k}=\frac{\operatorname{In} 2}{4}$

Because there are insufficient quantitative data to describe the processes of the insulin effect from binding to receptor through to alterations in metabolism, we assigned the same value of $(\ln 2) / 4$ to $\mathrm{k}_{1}$ and to $\mathrm{k}_{2}$, the velocity rate constants to and from the effector compartment:

$$
\frac{\mathrm{dIe}}{\mathrm{dt}}=\mathrm{k}_{1} \mathrm{I}-\mathrm{k}_{2} \mathrm{Ie}
$$

Insulin delivery rate depends upon the glucose concentration profile over the preceding $120 \mathrm{~min}$ and upon the pancreatic $\beta$-cell efficiency factor. A sigmoidal, steadily increasing curve describes the relationship between pancreatic activity and glucose concentration, with activity one-sixteenth of maximal in a steady basal state, where glucose concentration is $4 \mathrm{mmol} / 1[18-20]$.

$$
\begin{gathered}
\mathrm{f}_{\mathrm{f}}(\mathrm{G}) \text { : pancreatic activity function. } \\
\mathrm{f}_{\mathrm{I}}(4)=11.3 \mathrm{mU} / \mathrm{min} \text { (basal) } \\
\lim _{\mathrm{G} \rightarrow \infty} \mathrm{f}_{\mathrm{I}}(\mathrm{G})=16 \times 11.3 \text { (maximum) }
\end{gathered}
$$

where $\frac{\mathrm{df}_{\mathrm{I}}}{\mathrm{dG}}>0$

A biphasic time course function of insulin release, with a 'first phase' and 'second phase' [21], represents output as a fraction of basal versus time elapsed since stimulus. The first phase is maximal between 2 and $3 \mathrm{~min}$, dying away by $5 \mathrm{~min}$, and the second phase gradually builds up to $100 \%$ of steady state basal output:

$\mathrm{PH}(\mathrm{t})$ : phase factor

This multiplies $\Delta \mathrm{f}_{\mathrm{I}}(\mathrm{G})$, so that the actual output is dependent on time as well as glucose.

The insulin delivery rate is the sum of the most recent increments in pancreatic activity from zero to the value at the time of evaluation multiplied by the corresponding phase magnification factor:

$\operatorname{IDR}\left(\mathrm{t}_{0}\right)$ was evaluated by considering the glucose profile

$$
\mathrm{G}=\mathrm{G}\left(\mathrm{t}_{0}-\mathrm{t}\right) \text { where } 0<\mathrm{t}<120
$$

An 'inverse' $T(G)$ is defined on the domain $G=\left[0<G<G\left(t_{0}\right)\right]$ as follows:

$T(G)= \begin{cases}\min & {\left[t: G\left(t_{0}-t\right)=G\right]} \\ 0<t<120 & \\ 120 & \text { if } G\left(t_{0}-t\right) \neq G \text { for any } t 0<t<120\end{cases}$

$\operatorname{IDR}\left(\mathrm{t}_{0}\right)=\mathrm{B} \int_{0}^{\mathrm{G}\left(\mathrm{t}_{0}\right)} \frac{\mathrm{df_{I }}(\mathrm{G})}{\mathrm{dG}} \mathrm{PH}(\mathrm{T}(\mathrm{G})) \mathrm{dG}$

$\beta$-cell efficiency is the ability of the pancreas to respond to glucose. Insulin resistance represents any defect in responding to insulin. There is no standard way of quantitating these two characteristics, each of which has for simplicity been expressed as a ratio to the mean of values of non-diabetic normal weight subjects aged $<35$ years. Since B multiplies insulin delivery rate (usually by a number $<1$ for the diabetics $[5,8]$ ), it is a measure of $\beta$-cell efficiency and this has been expressed in the CIGMA estimates as percentage of normal $\beta$ cell function. $R$, the measure of insulin resistance, is the ratio given by the actual level of insulin in a subject divided by the amount of insulin which would achieve the same effect in a non-diabetic 'standard' subject. The accuracy of the derived values depends on the model's assumptions and revised parameters might give improved results.

Final adjustment of computer model. Information concerning $\beta$-cell time responses in man is scanty. $\beta$-cell first and second-phase values 
derived from rats [21] were empirically adjusted to fit observations of human insulin response to an intravenous bolus of glucose; these data were independent of those used elsewhere in this study. The subjects [20] were 10 women (ideal body weight $102-113 \%$, mean age 32 years) [7]. A bolus of glucose $0.2 \mathrm{~g} / \mathrm{kg}$ (as a solution of $50 \mathrm{~g} / 100 \mathrm{ml}$ ) was infused over $2 \mathrm{~min}$ through an indwelling Teflon cannula (Venflon, Viggo B, Helsingborg, Sweden). The mean increments in glucose and in-

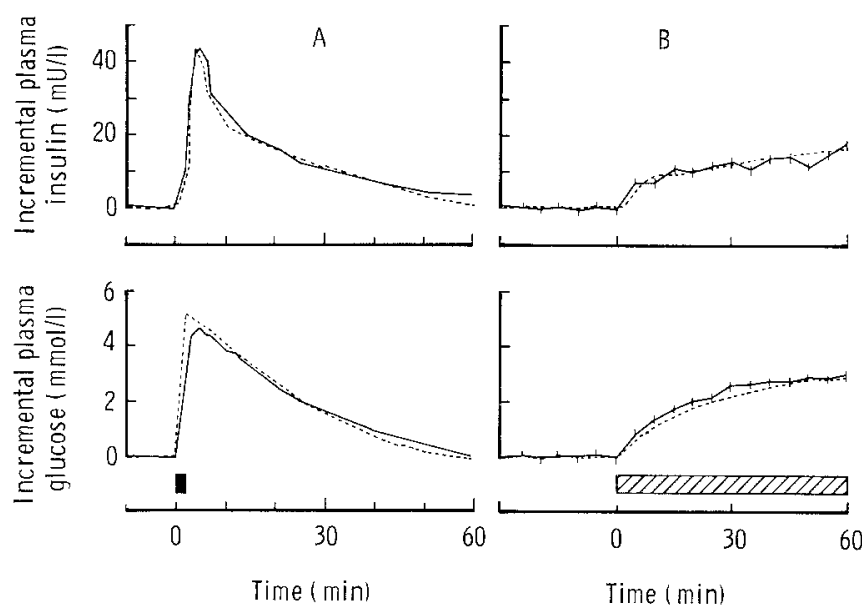

Fig. 1. A Adjustment of time course of $\beta$-cell response to glucose in the model to fit plasma insulin and glucose concentrations during intravenous glucose tolerance test. — incremental plasma glucose and insulin concentrations during an intravenous glucose tolerance test ( $0.2 \mathrm{~g}$ glucose $/ \mathrm{kg}$ ideal body weight over $2 \mathrm{~min} /$ in 10 normal-weight, non-diabetic young women). ----- incremental plasma glucose and insulin concentrations as predicted by the model, assuming normal insulin resistance and $\beta$-cell function, after the model's insulin-release time function had been adjusted to fit these experimental data. B The predictions by the model of plasma glucose and insulin responses to a continuous glucose infusion. - incremental plasma glucose and insulin concentrations ( $\pm \mathrm{SEM}$ ) during a continuous infusion $(5 \mathrm{mg}$ glucose $/ \mathrm{kg}$ ideal body weight per min, in eight normal-weight, non-diabetic young men). ---- incremental plasma glucose and insulin concentrations predicted by the model for this infusion, with no further adjustment made of any parameters sulin concentrations during the intravenous glucose tolerance test were plotted as the solid lines in Figure $1 \mathrm{~A}$. Without altering any of the data in the model other than the $\beta$-cell time course, a good fit of the model insulin responses was obtained (dashed line, Fig. $1 \mathrm{~A}$ ).

The model, with its adjusted $\beta$-cell time course, was then used to predict the incremental glucose and insulin values of a continuous infusion of glucose for $60 \mathrm{~min}$, for normal insulin resistance and $\beta$-cell function (dashed line Fig. 1 B). This closely fitted the mean incremental glucose and insulin values during continuous infusion of glucose performed in eight young men (aged 22-29 years, 96-107\% ideal body weight) (continuous line Fig. 1 B).

Model prediction of responses for varying degrees of insulin resistance and $\beta$-cell function. The model was used to predict a series of mean plasma glucose and insulin responses from 45 to $60 \mathrm{~min}$ of continuous infusion of glucose for differing degrees of insulin resistance and $\beta$ cell function. The concentrations achieved are plotted in Figure 2.

\section{Investigation methods}

The studies were approved by the Oxford District Ethics Committee and all subjects gave informed consent.

Continuous infusion of glucose. In fasting subjects attending from home, integrated 1 min samples were taken through a double-lumen Teflon cannula, heparinised at the tip by infusion of heparin through the outer concentric lumen of the cannula (1/100 of the volume of the blood sample) to achieve a final concentration of $50 \mathrm{U}$ heparin $/ \mathrm{ml}$ in the sample. The hand was kept warm with an electric heating pad so that the blood samples, taken from the indwelling venous cannula on the back of the hand, were similar to arterial blood. The fasting plasma glucose and insulin values were assessed from the mean of the last 13 one-min samples of a 30-min run-in-period, to allow for the 14-min periodicity of insulin secretion [22]. A continuous intravenous infusion of $5 \mathrm{mg}$ glucose $/ \mathrm{kg}$ ideal body weight per min was then started and continued for $60 \mathrm{~min}$. Doses calculated by ideal body weight [7] provide approximately equivalent plasma glucose concentrations, whereas use of actual body weight gives higher plasma glucose concentrations in obese than in normal-weight subjects. Urine was tested for glucose at the end of the infusion. The mean plasma glucose and insulin values over the last 13 observations before the end of the infusion were calculated. In clinical practice, virtually identical results can be obtained by a mean of three samples taken at 50,55 and $60 \mathrm{~min}$.

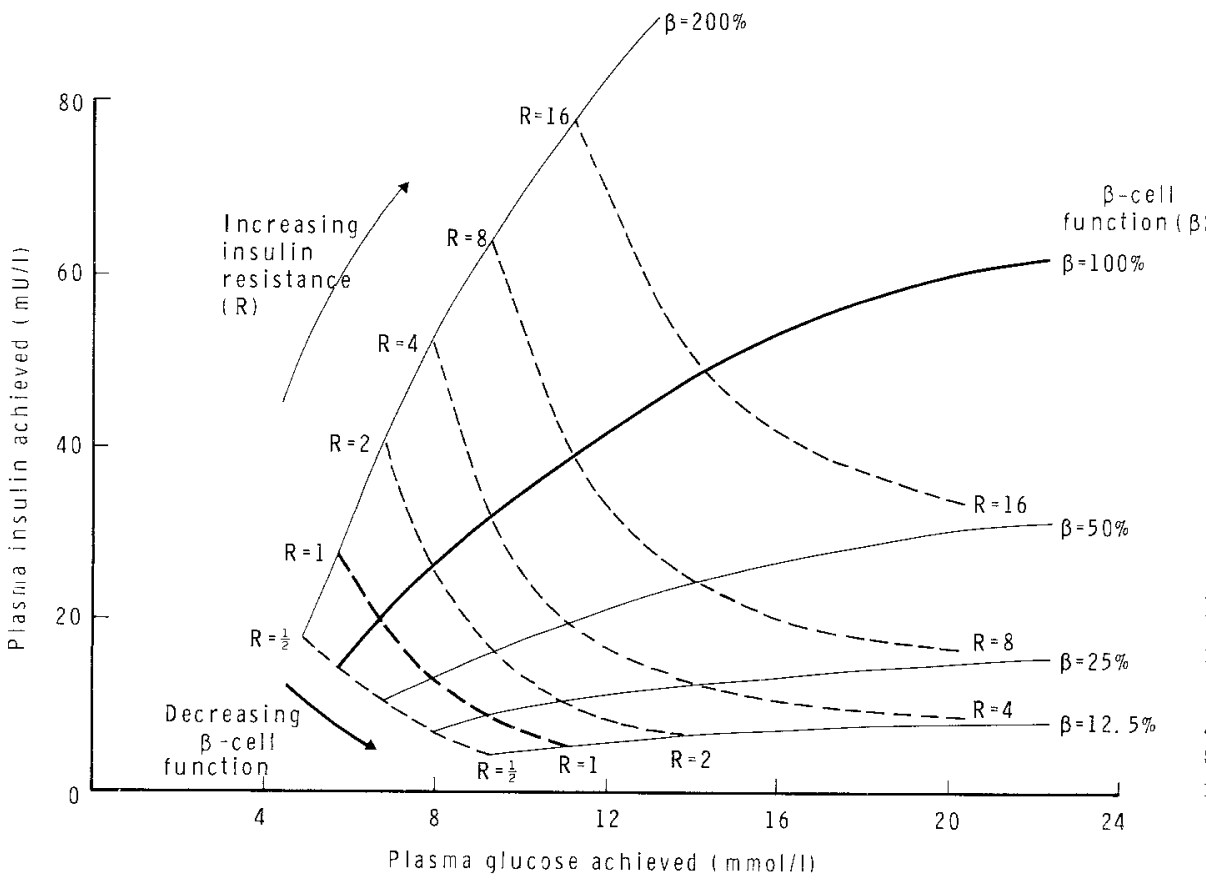

Fig. 2. Computer model predictions for plasma glucose and insulin concentrations achieved after a 60 -min glucose infusion. The grid represents a series of values predicted by the model for mean plasma glucose and insulin concentrations achieved over the last $15 \mathrm{~min}$ of a $60 \mathrm{~min}$ infusion of $5 \mathrm{mg}$ glucose $/ \mathrm{kg}$ ideal body weight per min, for subjects with different degrees of insulin resistance (----) and $\beta$-cell function (-) 


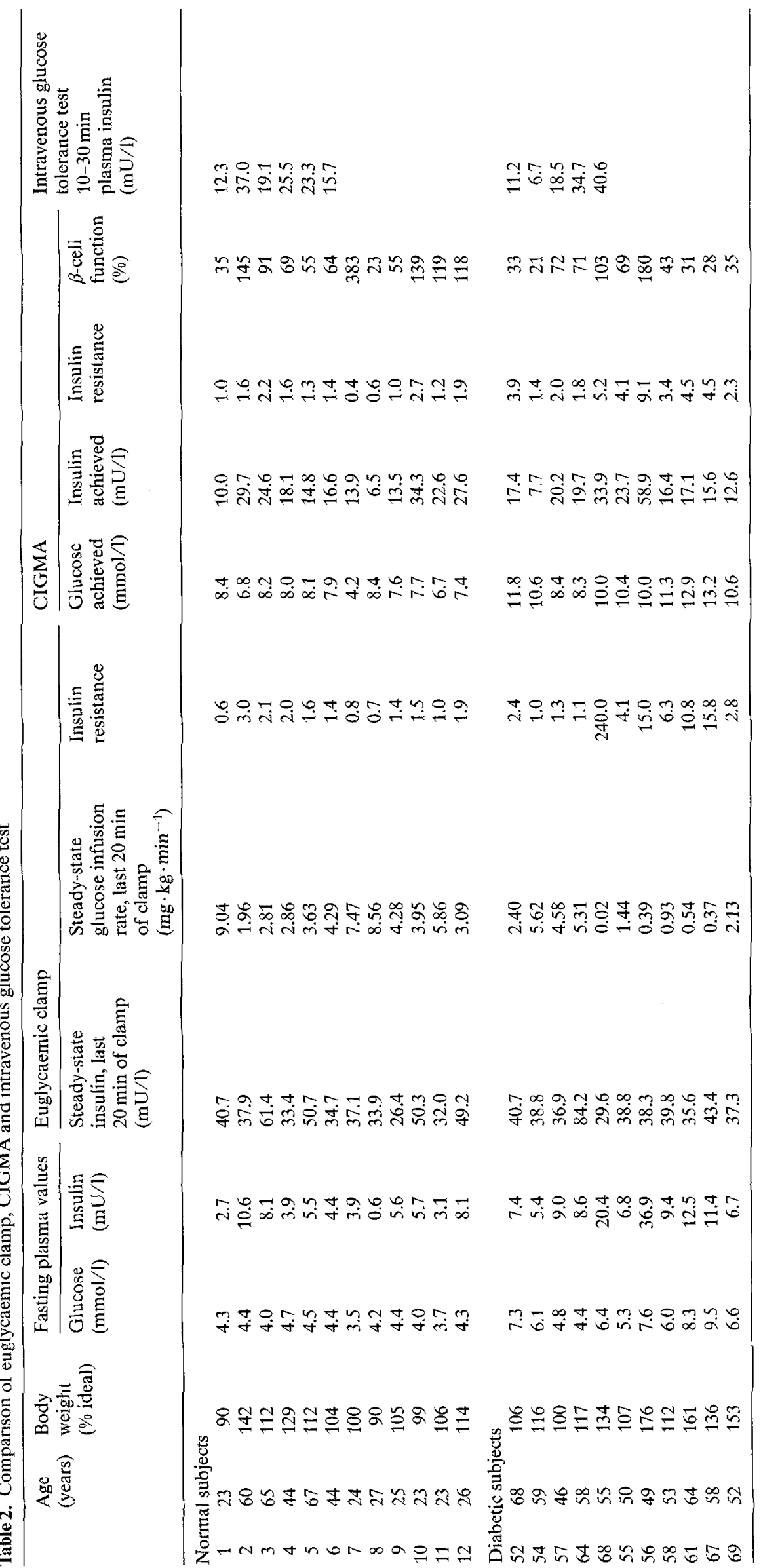




\section{Comparison of insulin resistance measured by CIGMA and the euglycaemic clamp}

Twelve normal subjects (aged 23-67 years, 90-142\% ideal body weight) and 11 Type 2 diabetic patients treated by diet alone (aged 46-68 years, $100-176 \%$ ideal body weight) were studied (Table 2). All were on a weight-maintaining diet containing more than $200 \mathrm{~g}$ carbohydrate per day. The clinical characteristics of the diabetic subjects are shown in Table 3. Each attended fasting on two occasions, once for a CIGMA and once for euglycaemic hyperinsulinaemic clamp. Hyperinsulinaemia was induced by an infusion of $50 \mathrm{mU}$ insulin $/ \mathrm{min}$ per $70 \mathrm{~kg}$ ideal body weight through an intravenous cannula placed in the antecubital vein. Maintenance of euglycaemia (plasma glucose $4.5 \mathrm{mmol} / 1$ for all subjects) utilised an iterative learning computer program [23] designed to estimate glucose requirements from samples taken every $2 \mathrm{~min}$ by a rotary pump through a double-lumen cannula from a distal arterialised forearm vein, as above for CIGMA. These samples were analysed immediately by a glucose-oxidase method (Beckman RIIC, High Wycombe, Bucks, UK, coefficient of variation $2.1 \%$ ) and the result entered into a $380 \mathrm{Z}$ microcomputer (Research Machines, Oxford, UK) within 2 min of sampling. Adequate glucose clamping was defined by the following criteria: (1) 20 consecutive plasma glucose values all within the range $4.0-5.0 \mathrm{mmol} / \mathrm{l}$, and (2) mean glucose infusion rates over the two preceding 20 -min periods within $90-110 \%$ of each other. The reciprocal of the glucose infusion rate during the last $40 \mathrm{~min}$ normalised to the median of the normal group (age $<35$ years, $90-110 \%$ ideal body weight), gives a value of relative insulin resistance. Thus a glucose infusion rate of $0.59 \mathrm{~g} / \mathrm{min}$ for a $70 \mathrm{~kg}$ subject represents an insulin resistance of 1.

\section{Comparison of $\beta$-cell function and insulin resistance values measured CIGMA with those measured using the hyperglycaemic clamp}

Ten normal subjects (aged 22-69 years, $90-113 \%$ ideal body weight) and 11 Type 2 diabetic patients on diet alone (aged 40-69 years, 97-174\% ideal body weight) were studied (Table 4). Each subject was studied twice: once with a CIGMA test as described above, and once with hyperglycaemic clamp lasting $2.5 \mathrm{~h}$ at a plasma glucose concentration of $10 \mathrm{mmol} / 1$. No exogenous insulin was infused since it was wished to measure the endogenous insulin response. Otherwise the method was as described for euglycaemic clamp. Each subject was assessed for glycosuria at the end of the clamp. Plasma insulin levels during the last $20 \mathrm{~min}$ of the hyperglycaemic clamp were used to assess $\beta$-cell function, expressed as percent of the median value in normal subjects $(33 \mathrm{mU} / \mathrm{l})$. Insulin resistance was calculated by dividing the mean plasma insulin over the last $20 \mathrm{~min}$ of the hyperglycaemic clamp by the mean glucose infusion rate over the same period, and was normalised to the median for normal-weight, normal subjects. Thus an insulin resistance of 1 represents $0.18 \times$ [mean plasma insulin (mU/l)]/[mg glucose infused $/ \mathrm{kg}$ body weight per min].

\section{Comparison of $\beta$-cell function measured by CIGMA and the intravenous glucose tolerance test}

Six of the normal subjects from Table 2 (aged 23-67 years, 90-142\% ideal body weight), and five of the diabetic subjects from Table 2 (aged 46-68 years, 100 -134\% ideal body weight) were also studied using the intravenous glucose tolerance test. Subjects were rested overnight in hospital and the same blood sampling technique was used as for the euglycaemic hyperinsulinaemic clamp. Samples were taken each minute, and after a 5 -min basal sampling period a glucose bolus of $0.2 \mathrm{~g} / \mathrm{kg}$ ideal body weight was given over $2 \mathrm{~min}$ through a second Teflon cannula (Venflon) inserted into an antecubital vein. Sampling was continued for $45 \mathrm{~min}$ after the bolus infusion. The mean plasma insulin concentration from 10 to 30 min after the start of the bolus infusion was used as the measure of $\beta$-cell function.
Table 3. Characteristics of diabetic subjects in study

\begin{tabular}{|c|c|c|c|c|c|c|}
\hline \multirow{2}{*}{$\begin{array}{l}\text { Sub- } \\
\text { ject } \\
\text { no. }\end{array}$} & \multirow[t]{2}{*}{$\begin{array}{l}\text { Presenting } \\
\text { symptom }\end{array}$} & \multicolumn{3}{|c|}{ Features at presentation } & \multicolumn{2}{|c|}{$\begin{array}{l}\text { Features at time } \\
\text { of investigation }\end{array}$} \\
\hline & & $\begin{array}{l}\text { Fasting } \\
\text { plasma } \\
\text { glucose } \\
(\mathrm{mmol} / \mathrm{l})\end{array}$ & $\begin{array}{l}\text { Body } \\
\text { weight } \\
\text { (kg) }\end{array}$ & $\begin{array}{l}\text { Duration } \\
\text { of } \\
\text { symptoms } \\
\text { (years) }\end{array}$ & $\begin{array}{l}\text { Fasting } \\
\text { plasma } \\
\text { glucose } \\
(\mathrm{mmol} / \mathrm{l})\end{array}$ & $\begin{array}{l}\text { Body } \\
\text { weight } \\
(\mathrm{kg})\end{array}$ \\
\hline 51 & Thirst & 7.5 & 94 & 1 & 5.2 & 79 \\
\hline 52 & Thirst & 14.5 & 77 & 3 & 7.1 & 71 \\
\hline 53 & Polyuria & 16.0 & 76 & 4 & 6.4 & 71 \\
\hline 54 & Nocturia & 7.9 & 85 & 3 & 6.1 & 78 \\
\hline 55 & Incidental & 14.6 & 82 & 6 & 5.3 & 74 \\
\hline 56 & Thirst & 8.9 & 87 & 6 & 7.6 & 87 \\
\hline 57 & Infection & 7.5 & 62 & 2 & 4.8 & 57 \\
\hline 58 & Nocturia & 9.6 & 67 & 5 & 6.0 & 67 \\
\hline 59 & Infection & 7.1 & 73 & 3 & 5.0 & 63 \\
\hline 60 & Retinopathy & 11.8 & 104 & 2 & 5.2 & 81 \\
\hline 61 & Incidental & 8.1 & 89 & 4 & 8.3 & 83 \\
\hline 62 & Incidental & 9.7 & 119 & 1 & 6.5 & 107 \\
\hline 63 & Weight loss & 7.4 & 72 & 6 & 6.4 & 66 \\
\hline 64 & Thirst & 18.4 & 93 & 4 & 4.4 & 80 \\
\hline 65 & Balanitis & 6.9 & 72 & 3 & 5.6 & 60 \\
\hline 66 & Candidiasis & 6.5 & 63 & 1 & 5.1 & 60 \\
\hline 67 & Incidental & 11.4 & 86 & 3 & 9.5 & 83 \\
\hline 68 & Weight loss & 9.8 & 84 & 5 & 6.4 & 83 \\
\hline 69 & Thirst & 12.8 & 84 & 6 & 6.6 & 82 \\
\hline 70 & Thirst & 6.8 & 63 & 3 & 6.6 & 60 \\
\hline
\end{tabular}

\section{Reproducibility of insulin resistance and $\beta$-cell function as measured by CIGMA}

Nine normal subjects (aged 22-29 years, 96-107\% ideal body weight) and nine Type 2 diabetic subjects treated by diet only (aged 46-68 years, $106-188 \%$ ideal body weight) had two CIGMAs on separate days within 3 weeks. The fasting plasma glucose was $4.2 \pm$ $0.2 \mathrm{mmol} / 1$ in normal subjects and $6.2 \pm 0.9 \mathrm{mmol} / 1$ in diabetic subjects. Subjects were asked to adhere to the same diet over this time. The values from CIGMA for insulin resistance and $\beta$-cell function were compared on the two occasions and a coefficient of variation of duplicates was calculated for each of these measures using the formula:

$$
\frac{\sqrt{\frac{\sum(\text { difference })^{2}}{2 n}}}{\text { mean }}
$$

\section{Assays and statistical analysis}

Insulin and C-peptide levels were assayed by charcoal-phase separation radioimmunoassay [24], with a between-assay coefficient of variation of 11-16\%. Glucose was measured by a glucose-oxidase method (Boehringer GOD-Perid, Boehringer Corporation London, Lewes, Sussex, UK). The results were analysed using non-parametric (Spearman rank correlation coefficient) and parametric statistical tests (Student's t-test).

\section{Results}

\section{Plasma glucose responses to CIGMA}

The mean plasma glucose level achieved over the last $15 \mathrm{~min}$ of the $60 \mathrm{~min}$ infusion correlated with the fasting plasma glucose for the total of 72 CIGMAs performed ( 38 normal and 34 diabetic subjects), and provided a 
Table 4. Comparison of CIGMA with hyperglycaemic clamp

\begin{tabular}{|c|c|c|c|c|c|c|c|c|c|c|c|}
\hline \multirow{2}{*}{$\begin{array}{l}\text { Sub- } \\
\text { ject } \\
\text { no. }\end{array}$} & \multirow{2}{*}{$\begin{array}{l}\text { Age } \\
\text { (years) }\end{array}$} & \multirow{2}{*}{$\begin{array}{l}\text { Body } \\
\text { weight } \\
\text { (\% ideal) }\end{array}$} & \multicolumn{2}{|c|}{ Fasting plasma values } & \multicolumn{3}{|c|}{ Hyperglycaemic clamp (last 20 min) } & \multicolumn{4}{|c|}{ CIGMA (last $15 \mathrm{~min}$ ) } \\
\hline & & & $\begin{array}{l}\text { Glucose } \\
(\mathrm{mmol} / \mathrm{l})\end{array}$ & $\begin{array}{l}\text { Insulin } \\
(\mathrm{mU} / \mathrm{l})\end{array}$ & $\begin{array}{l}\text { Mean } \\
\text { plasma } \\
\text { insulin } \\
(\mathrm{mU} / \mathrm{l})\end{array}$ & $\begin{array}{l}\text { Mean glucose } \\
\text { infusion rate } \\
\left(\mathrm{mg} \cdot \mathrm{kg} \cdot \mathrm{min}^{-1}\right)\end{array}$ & $\begin{array}{l}\text { Insulin } \\
\text { resistance }\end{array}$ & $\begin{array}{l}\text { Mean } \\
\text { plasma } \\
\text { glucose } \\
(\mathrm{mmol} / \mathrm{l})\end{array}$ & $\begin{array}{l}\text { Mean } \\
\text { plasma } \\
\text { insulin } \\
(\mathrm{mU} / 1)\end{array}$ & $\begin{array}{l}\text { Insulin } \\
\text { resistance }\end{array}$ & $\begin{array}{l}\beta \text {-cell } \\
\text { function } \\
(\%)\end{array}$ \\
\hline \multicolumn{12}{|c|}{ Normal subjects } \\
\hline 13 & 22 & 107 & 4.8 & 5.5 & 18.1 & 7.36 & 0.44 & 6.6 & 19.0 & 1.0 & 104 \\
\hline 3 & 66 & 113 & 4.5 & 6.0 & 32.8 & 3.08 & 1.91 & 9.7 & 19.4 & 2.8 & 61 \\
\hline 6 & 45 & 103 & 4.4 & 4.9 & 34.1 & 7.31 & 0.84 & 9.0 & 22.2 & 2.7 & 77 \\
\hline 14 & 32 & 112 & 4.3 & 5.1 & 39.6 & 4.51 & 1.58 & 8.7 & 29.7 & 3.2 & 100 \\
\hline 15 & 67 & 109 & 4.6 & 5.1 & 14.9 & 2.75 & 0.97 & 9.0 & 16.1 & 1.9 & 56 \\
\hline 16 & 22 & 95 & 5.2 & 6.8 & 79.4 & 11.88 & 1.20 & 8.2 & 29.7 & 2.7 & 109 \\
\hline 17 & 23 & 95 & 4.7 & 6.9 & 75.0 & 14.01 & 0.96 & 7.2 & 20.8 & 1.3 & 93 \\
\hline 18 & 21 & 105 & 4.7 & 6.9 & 28.9 & 4.99 & 1.04 & 7.6 & 15.1 & 1.1 & 62 \\
\hline 19 & 69 & 99 & 5.5 & 3.8 & 41.4 & 7.86 & 0.95 & 7.6 & 11.2 & 0.8 & 46 \\
\hline 8 & 28 & 90 & 5.0 & 5.1 & 25.2 & 9.27 & 0.49 & 8.0 & 7.9 & 0.7 & 30 \\
\hline \multicolumn{12}{|c|}{ Diabetic subjects } \\
\hline 52 & 69 & 98 & 7.1 & 7.6 & 7.1 & 0.37 & 3.45 & 12.9 & 10.9 & 2.9 & 20 \\
\hline 60 & 40 & 111 & 5.2 & 8.9 & 15.6 & 2.94 & 0.95 & 9.0 & 15.5 & 1.9 & 53 \\
\hline 69 & 52 & 158 & 6.5 & 4.0 & 8.4 & 1.03 & 1.46 & 11.0 & 13.3 & 2.8 & 36 \\
\hline 62 & 57 & 174 & 6.5 & 12.0 & 35.4 & 1.66 & 3.83 & 9.1 & 32.8 & 4.1 & 112 \\
\hline 59 & 49 & 131 & 5.0 & 11.4 & 22.8 & 3.57 & 1.15 & 9.4 & 19.0 & 2.6 & 62 \\
\hline 51 & 45 & 118 & 5.2 & 8.5 & 32.1 & 1.52 & 3.79 & 9.6 & 22.7 & 3.2 & 72 \\
\hline 53 & 46 & 106 & 6.4 & 15.0 & 25.0 & 4.56 & 0.98 & 9.1 & 27.2 & 3.4 & 93 \\
\hline 63 & 68 & 106 & 6.4 & 4.5 & 6.9 & 2.41 & 0.51 & 10.7 & 8.5 & 1.6 & 23 \\
\hline 70 & 58 & 103 & 6.0 & 2.5 & 7.4 & 3.20 & 0.41 & 10.8 & 8.9 & 1.7 & 24 \\
\hline 65 & 55 & 97 & 5.6 & 4.5 & 23.0 & 4.88 & 0.85 & 9.9 & 11.0 & 1.7 & 34 \\
\hline 66 & 50 & 97 & 5.1 & 11.0 & 40.2 & 4.85 & 1.49 & 11.3 & 19.4 & 4.0 & 51 \\
\hline
\end{tabular}

measure of glucose intolerance (Fig. 3). The plasma glucose of normal subjects rose from a fasting value of $4.4 \pm 0.4 \mathrm{mmol} / \mathrm{l}($ mean $\pm \mathrm{SD})$ to a $45-60 \mathrm{~min}$ value of $7.7 \pm 0.8 \mathrm{mmol} / \mathrm{l}$. The plasma glucose of the diabetic subjects rose from $6.2 \pm 1.1$ fasting to $10.4 \pm 1.3 \mathrm{mmol} / \mathrm{l}$. The bi-variate regression line for all subjects was: (plasma glucose achieved at $45-60 \mathrm{~min})=($ fasting plasma glucose $\times 1.46)+1.2$.

\section{Comparison of insulin resistance measured by CIGMA with that measured by euglycaemic hyperinsulinaemic clamp (Table 2)}

Quality of euglycaemic hyperinsulinaemic clamps. The median duration of the clamps in normal subjects was $130 \mathrm{~min}$ (range 110-164 min) and in Type 2 diabetic subjects was $132 \mathrm{~min}$ (range $100-210 \mathrm{~min}$ ). The range of mean plasma insulin values over the last $20 \mathrm{~min}$ of each clamp was $26.4-84.2 \mathrm{mU} / 1$ with a median of $38.3 \mathrm{mU} / 1$. Mean \pm SD fasting plasma C-peptide in normal subjects was $0.36 \pm 0.13 \mathrm{nmol} / 1$, and was suppressed to $0.09 \pm 0.07 \mathrm{nmol} / 1$ over the last $20 \mathrm{~min}$ of each subject's clamp. In diabetic subjects, fasting C-peptide was $0.57 \pm 0.18 \mathrm{nmol} / \mathrm{l}$, and suppressed to $0.16 \pm$ $0.10 \mathrm{nmol} / 1$ over the last $20 \mathrm{~min}$.

The mean \pm SD of individual subjects' mean plasma glucose concentrations over the last $40 \mathrm{~min}$ of the euglycaemic clamp (20 values for each subject) was $4.5 \pm$ $0.1 \mathrm{mmol} / 1$. The mean \pm SD of individual subjects' co- efficients of variation of the plasma glucose over the same period was $5.2 \pm 2.0 \%$.

Comparison of insulin resistance measurements. The insulin resistance measured by CIGMA correlated with that measured using the euglycaemic hyperinsulinaemic clamp, in normal subjects (Spearman rank correlation coefficient $\mathrm{R}_{\mathrm{s}}=0.79, p<0.002$ ), diabetic subjects $\left(\mathrm{R}_{\mathrm{s}}=0.91, p<0.002\right)$ and in both groups combined $\left(\mathrm{R}_{\mathrm{s}}=0.87, p<0.0001\right)$ (Fig. 4). The relationship between the values by the two methods in diabetic subjects was non-linear, with higher values in five subjects when measured by the euglycaemic hyperinsulinaemic clamp. These subjects had high fasting plasma insulin concentrations $(9-37 \mathrm{mU} / 1)$. The range of insulin resistance measured by both methods in normal subjects was approximately $0.5-3.0$. The median resistance in normal subjects was 1.35 by CIGMA and 1.45 by euglycaemic hyperinsulinaemic clamp, and in diabetic subjects was 3.9 by CIGMA and 4.1 by the clamp. No subject had glycosuria exceeding $5 \mathrm{mmol} / 1$ at the end of the CIGMA tests.

Comparison of insulin resistance measured by CIGMA and that measured by hyperglycaemic clamp (Table 4)

Quality of hyperglycaemic clamps. The mean \pm SD of the individual subjects' mean plasma glucose concentrations over the last $40 \mathrm{~min}$ of the clamp ( 20 values for 
each subject) was $9.9 \pm 0.2 \mathrm{mmol} / \mathrm{l}$, with a mean coefficient of variation of $3.6 \%$. No subject had glycosuria exceeding $5 \mathrm{mmol} / \mathrm{l}$.

Comparison of insulin resistance measurement. The CIGMA estimate of insulin resistance correlated with that measured by hyperglycaemic clamp in normal subjects alone $\left(\mathrm{R}_{\mathrm{s}}=0.75, p<0.02\right)$, in diabetic subjects alone $\left(\mathrm{R}_{\mathrm{s}}=0.82, p<0.005\right)$ and in both groups together $\left(\mathrm{R}_{\mathrm{s}}=0.78, p<0.0001\right.$; Fig. 4$)$. The range of insulin resistance values in normal subjects was $0.7-3.2$ by CIGMA, and $0.4-1.9$ by hyperglycaemic clamp. The median resistance in normal subjects was 1.6 by CIGMA and 0.97 by hyperglycaemic clamp, and in diabetic subjects it was 2.8 by CIGMA and 1.1 by hyperglycaemic clamp.

\section{Comparison of different measurements of insulin resistance with body weight and fasting plasma insulin}

Obesity, expressed as percent ideal body weight, was correlated with insulin resistance measured by euglycaemic hyperinsulinaemic clamp in normal subjects alone $\left(\mathrm{R}_{\mathrm{s}}=0.87, p<0.0001\right)$, in diabetic subjects alone $\left(R_{s}=0.54, N S\right)$ and in both groups together $\left(R_{s}=0.73\right.$, $p<0.0001$; Fig. $5 \mathrm{~A})$. The relationship between insulin resistance determined by CIGMA and body weight is shown in the lower part of Figure $5 \mathrm{~A}$; in normal subjects alone the correlation coefficient was $R_{s}=0.51$ $(p<0.05)$, in diabetic subjects alone $\mathrm{R}_{\mathrm{s}}=0.52$ (NS), and in both groups together $\mathrm{R}_{\mathrm{s}}=0.59(p<0.002)$.

Fasting plasma insulin correlated with insulin resistance measured by the euglycaemic hyperinsulinaemic clamp in normal subjects alone $\left(\mathrm{R}_{s}=0.83, p<0.0006\right)$, in diabetic subjects alone $\left(R_{s}=0.79, p<0.004\right)$ and in both groups together $\left(\mathrm{R}_{\mathrm{s}}=0.81, p<0.0001\right.$; Fig. $\left.5 \mathrm{~B}\right)$. Fasting plasma insulin correlated with CIGMA resistance in normal subjects $\left(\mathrm{R}_{\mathrm{s}}=0.75, p<0.003\right)$, in diabetic subjects $\left(\mathrm{R}_{\mathrm{s}}=0.80, p<0.004\right)$ and in both groups together $\left(\mathrm{R}_{\mathrm{s}}=0.84, p<0.0001\right)$.

The relationships between CIGMA estimates of insulin resistance and either ideal body weight or fasting plasma insulin concentration were more linear than the relationships between euglycaemic hyperinsulinaemic clamp estimates of insulin resistance and these indices.

\section{Reproducibility of estimate of insulin resistance by CIGMA}

The coefficients of variation of the CIGMA value for insulin resistance, from paired tests in nine normal and nine diabetic subjects, were $20 \%$ and $21 \%$, respectively.

The repeat CIGMA profiles for the nine normal subjects were segregated according to the member of each pair that gave the highest achieved insulin value. Throughout the infusion, the mean insulin and glucose profiles were higher in the tests with higher achieved insulin concentrations than in those with lower achieved insulin concentrations (Fig. 6). The difference in fasting

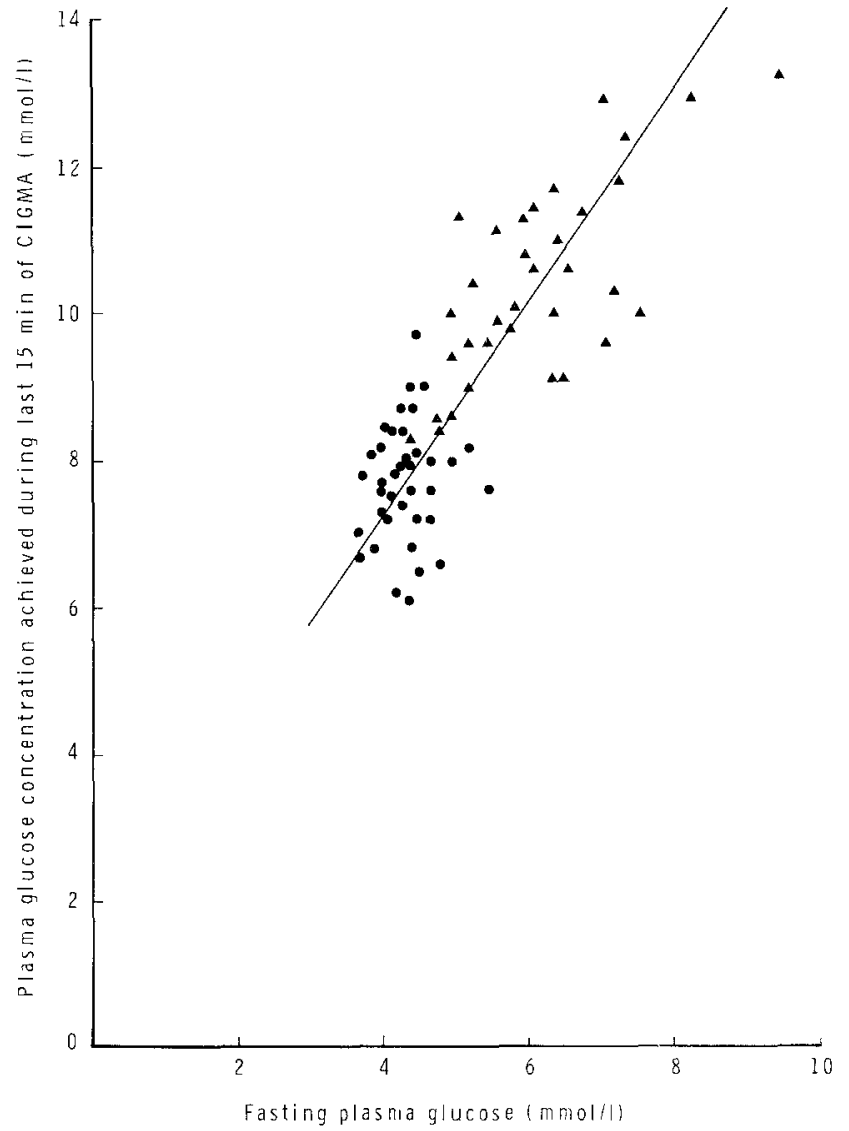

Fig. 3. Comparison of plasma glucose concentration when fasting with that of glucose after 60 min of continuous glucose infusion in 37 normal (O) and 34 diabetic $(\Delta)$ subjects. Correlation coefficient $r=0.83(p<0.0001)$

plasma glucose was statistically significant (Student's t-test, paired $\mathrm{t}=2.27, p<0.05$ ).

Comparison of $\beta$-cell function measured by CIGMA with that measured by hyperglycaemic clamp

$\beta$-cell function measured by CIGMA correlated significantly with the $\beta$-cell function measured by the hyperglycaemic clamp in diabetic subjects $\left(\mathrm{R}_{\mathrm{s}}=0.80, p<\right.$ $0.005)$ but not in normal subjects alone $\left(R_{\mathrm{s}}=0.45\right)$. For both groups together, the correlation was $\mathrm{R}_{\mathrm{s}}=0.64(p<$ 0.002 ; Fig. $7 \mathrm{~B}$ ). The ranges of values for $\beta$-cell function in normal subjects were $30-109 \%$ by CIGMA and $45-240 \%$ by hyperglycaemic clamp (corresponding to plasma insulin 14.9-79.4 mU/1). The median values for $\beta$-cell function in normal subjects were $70 \%$ by CIGMA and $100 \%$ by hyperglycaemic clamp, and in diabetic patients were $51 \%$ by CIGMA and $69 \%$ by hyperglycaemic clamp.

\section{Comparison of $\beta$-cell function measured by CIGMA with that measured by intravenous glucose tolerance test}

The ranges of $\beta$-cell function measured by CIGMA in six normal and six diabetic subjects were $35-145 \%$ (me- 
dian $67 \%$ ) and $21-103 \%$ (median $71 \%$ ), respectively. The ranges of mean 10-30 min plasma insulin concentrations, calculated from the intravenous glucose tolerance test in the normal subjects and Type 2 diabetic patients, were $12.3-37 \mathrm{mU} / 1$ (median $21.2 \mathrm{mU} / 1$ ) and $6.7-40.6 \mathrm{mU} / 1$ (median $18.5 \mathrm{mU} / 1$ ), respectively. The relationship between these two measures of $\beta$-cell function was approximately linear (normal and diabetic

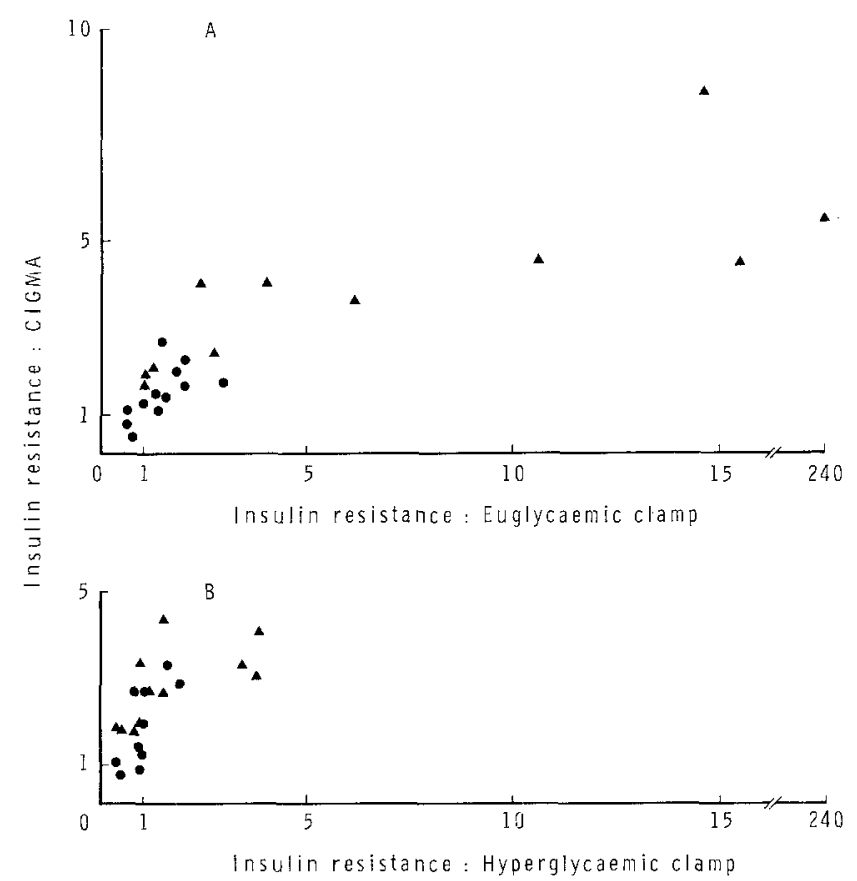

Fig. 4. Insulin resistance assessed by CIGMA compared with (A) values obtained by euglycaemic clamp in 12 normal (O) and 11 diabetic (A) subjects; (B) values obtained by hyperglycaemic clamp (a different cohort 10 normal and 11 diabetic subjects). The resistance values for CIGMA and both the clamps are expressed as ratios of the median value (defined as 1 ) in normal-weight normal subjects aged < 35 years (see Methods) subjects taken separately correlated $\mathrm{R}_{\mathrm{s}}=0.71$ (NS) and $0.98(p<0.01)$, respectively and for both groups together $\left(\mathrm{R}_{\mathrm{s}}\right)$ was $0.84, p<0.002$; Fig. $7 \mathrm{~A}$ ).

\section{Reproducibility of estimate of $\beta$-cell function by CIGMA}

When $\beta$-cell function was estimated by CIGMA in the nine normal men studied on two different days, one subject on one occasion did not increase his plasma glucose above $4 \mathrm{mmol} / 1$ and his data could not be read from the graph. The duplicate values of the remaining eight subjects correlated $\left(\mathrm{R}_{\mathrm{s}}=0.65, p<0.05\right)$, with a coefficient of variation of $19 \%$. The coefficient of variation for $\beta$-cell function on duplicate DIGMA tests in nine diabetic subjects was also $19 \%$.

\section{Discussion}

\section{Principles of CIGMA}

The steady-state mathematical model $[5,8]$ has been extended in this study to assess the glucose and insulin responses to a glucose infusion. A model incorporating the best available physiological data is used to interpret the observed responses. This incorporates more information on the body's metabolism than the minimal modelling approach using an intravenous glucose bolus [4]. In addition, a near-physiological glucose load is given, and the slowly changing homeostasis is more easily assessed. Both these modelling methods and the hyperglycaemic clamp examine the response to a patient's endogenous insulin secretion, and this approach may be superior to the euglycaemic hyperinsulinaemic clamp or insulin suppression test methods $[6,25]$, which use supraphysiological doses of insulin into the peripheral rather than the portal circulation. The model includes
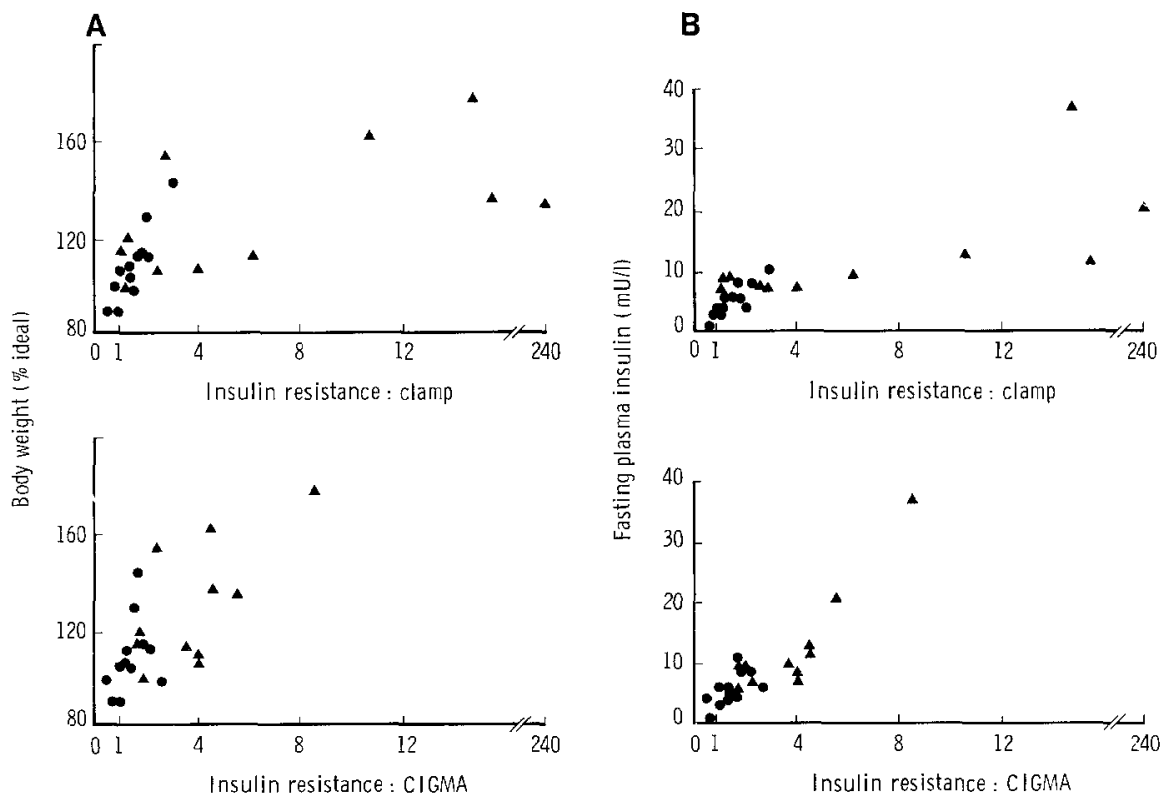

Fig.5. Comparison of (A) body weight ( $\%$ ideal) and (B) fasting plasma insulin levels with insulin resistance as assessed by (above) euglycaemic clamps and (below) CIGMA in the same group of subjects: normal $(n=12), \boldsymbol{\Delta}$ diabetic $(n=11)$ 

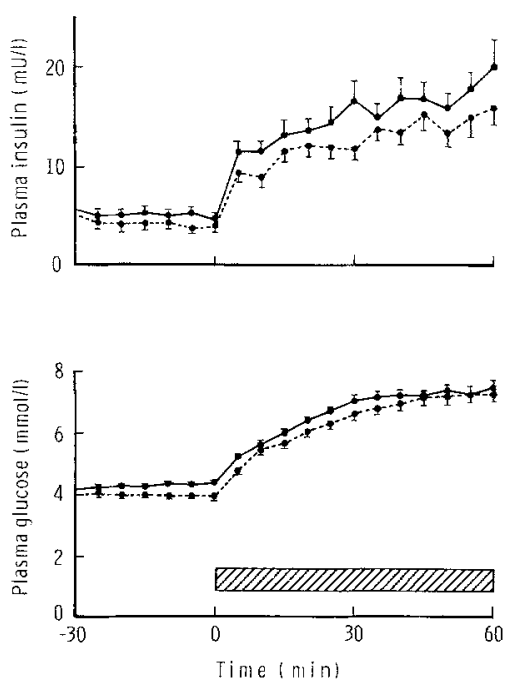

Fig. 6. CIGMA profiles performed on two occasions in nine young men, segregated on the basis of higher plasma insulin achieved at the end of the glucose infusion ( $5 \mathrm{mg}$ glucose $/ \mathrm{kg}$ body weight per min). - glucose and insulin profiles on the day with higher achieved plasma insulin (mean \pm SEM); --.-- similarly, day with lower achieved plasma insulin

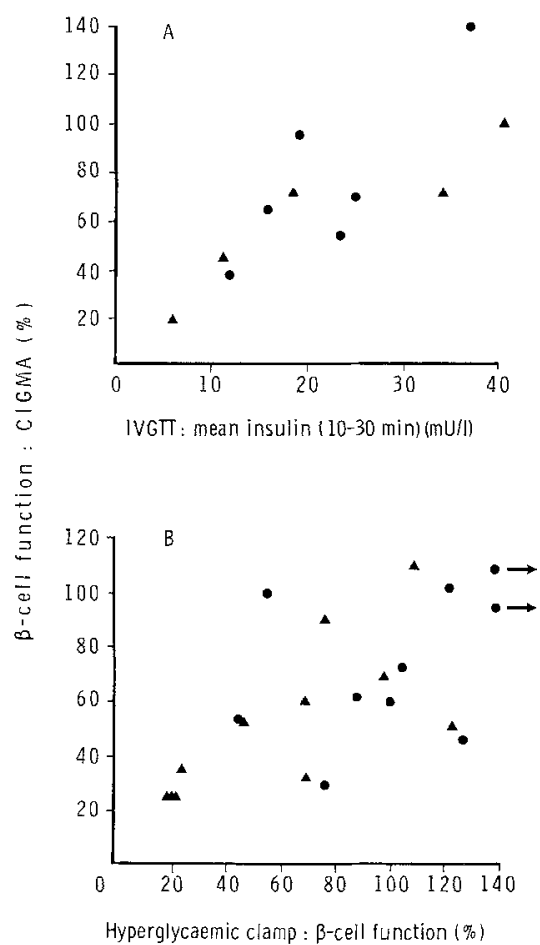

Fig. $7 \mathrm{~A}$ and B. $\beta$-cell function assessed by CIGMA compared with the values derived from $\mathbf{A}$ an intravenous glucose test (IVGTT) in six normal ( $)$ and five diabetic ( $\boldsymbol{\Delta})$ subjects and $\mathbf{B}$ an hyperglycaemic clamp in a different cohort of 10 normal and 11 diabetic subjects. The b-cell function in the hyperglycaemic clamp is expressed relative to the median achieved plasma insulin of normal-weight, normal subjects aged $<35$ years (see Methods)

response curves for different levels of glycaemia, so theoretically the insulin resistance and $\beta$-cell function values derived from CIGMA are independent of the glucose levels achieved. However, the model assessment assumes that the parameters of the model are relevant to the subjects studied. These assumptions include equality of insulin resistance at the liver and the periphery $[26,27]$ and that the reduction in $\beta$-cell function in diabetes is a quantitative decrease (i.e., decrease in $\mathrm{V}_{\max }$ ) [20]. Thus, the model may not be relevant in certain special situations; e.g. if there were a change of shape of the $\beta$-cell dose response curve. The use of the model assumes that the insulin assay used is accurate, giving a normal mean fasting plasma insulin of $5 \mathrm{mU} / 1$.

\section{CIGMA as a test of glucose tolerance}

Without any modelling of its results, the simple infusion of glucose can be considered as a test of glucose tolerance, analogous to the oral glucose tolerance test. The relationship between the fasting plasma glucose and the plasma glucose achieved between 45 and $60 \mathrm{~min}$ of CIGMA appears to be similar to that between the fasting plasma glucose and 2-h glucose value after an oral glucose tolerance test. Thus, a fasting plasma glucose of $7 \mathrm{mmol} / \mathrm{l}$ corresponds to a mean $45-60 \mathrm{~min}$ plasma glucose of $11.4 \mathrm{mmol} / 1$ during CIGMA. For comparison, the World Health Organisation diagnostic criteria for diabetes mellitus require a fasting capillary blood glucose more than $7 \mathrm{mmol} / 1$ or a value more than $11 \mathrm{mmol} / \mathrm{l}, 2 \mathrm{~h}$ after a 75-g glucose load [28].

\section{Validation of assessment of insulin resistance by CIGMA}

Insulin resistance as measured by CIGMA correlated with that measured by euglycaemic hyperinsulinaemic clamp. This relationship appeared to be non-linear in the diabetic subjects with the most marked insulin resistance (Fig. 4). This is probably due to an over-estimation by the clamp method, as we used a near-physiological dose of infused insulin, providing a median peripheral insulin concentration of $38 \mathrm{mU} / 1$, and this may have been insufficient to suppress hepatic glucose production in insulin-resistant patients who had high fasting insulin concentrations. By contrast, the insulin resistance values obtained by CIGMA correlated in a nearlinear manner with insulin resistance measured by the hyperglycaemic clamp. This may have reflected more complete suppression of hepatic glucose production by endogenous portal insulin during the hyperglycaemic clamp than during the euglycaemic hyperinsulinaemic clamp. The latter showed non-linearity with independent correlates of insulin resistance (fasting plasma insulin and body weight), whereas CIGMA resistance values correlated in a linear manner with these indices. A higher insulin dose in the euglycaemic clamp would probably have given more concordance [6], but there is a theoretical risk that pharmacological rather than physiological actions of insulin would then be assessed. Euglycaemic hyperinsulinaemic clamps may have other disadvantages as compared with CIGMA, including the fact that different subjects achieve different plasma insulin concentrations despite the same insulin infusion 
rate. In CIGMA, allowance is made for different insulin concentrations, and for separate hepatic and peripheral effects of insulin. This is more physiological than the euglycaemic clamp and insulin suppression tests $[6,29]$ which deliver insulin to the periphery.

There was a significant correlation between insulin resistance (measured either by CIGMA or by euglycaemic clamp) and body weight when the whole group of normal and diabetic subjects was considered, but not among diabetic subjects alone. Although the more obese diabetic subjects tended to be more insulin resistant, there was not a close correlation between the two variables. There may be inherent differences between subjects in respect of insulin resistance, as well as additional insulin resistance associated with hyperglycaemia $[30,31]$. CIGMA might have a role in screening diabetic subjects to identify those who are most insulin resistant and perhaps have more to gain by weight reduction.

\section{CIGMA estimate of $\beta$-cell function}

There was a significant correlation between the CIGMA and hyperglycaemic clamp estimates of $\beta$-cell function in diabetic but not in normal subjects. This difference contrasts with the ability of CIGMA to correlate with the insulin resistance values found in the clamp studies for normal and diabetic subjects alike. There may be important differences between normal and diabetic subjects in the glucose-insulin stimulus-response relationship of the $\beta$-cell, such that the model assumptions apply more to diabetic than to normal subjects. The correlation between CIGMA and hyperglycaemic clamp estimates of $\beta$-cell function in diabetic subjects was linear.

Comparison of the CIGMA estimate for $\beta$-cell function with the 10-30 min second phase response in the intravenous glucose tolerance tests also revealed a significant correlation, which appeared to be linear.

CIGMA could be used with C-peptide instead of insulin measurements. This may be advantageous as it assesses pancreatic secretion rather than the post-hepatic delivery rate and plasma proinsulin usually cross-reacts less with C-peptide than insulin assays. On the other hand, direct measurement of plasma insulin levels, the bio-active principle in the periphery, may have some advantages in assessing insulin resistance.

Insulin secretion is usually assessed by oral glucose tolerance tests. These are complex to analyse, partly because of variable gastric emptying, unquantified neural and enteric stimuli and a non-standard glycaemic stimulus to the $\beta$ cells. Although an intravenous glucose tolerance test is simpler, its value in assessing $\beta$-cell function and especially insulin resistance is uncertain. Mathematical models have been used to assess first and second phase $\beta$-cell responses [4]. These are rarely used in practice, and the intravenous glucose tolerance test has the theoretical problems of providing a rapid onset, supra-physiological stimulus, where mixing transients, rate of infusion, and timing of samples may all be critical.

\section{Reproducibility of CIGMA estimate of insulin resistance and $\beta$-cell function}

The variability of CIGMA could at best be as small as the inter-assay coefficient of variation of the insulin radioimmunoassay (which is $11-16 \%$ in this laboratory), as the plasma insulin value is used directly in the assessment. This is in contrast to the euglycaemic clamp [5] and the insulin suppression tests $[25,29]$ where the same amount of exogenous insulin is infused into each subject and the calculation of insulin resistance is made from glucose infusion data only. The euglycaemic clamp method can be subject to subtle bias from different experimenters' intentions, as shown by Greenfield et al. [32] who obtained a coefficient of variation of $17 \%$ for the difference in metabolic clearance rate between pairs of clamps. This is similar to our value for the coefficient of variation of $20 \%$ for insulin resistance measured by CIGMA in pairs of tests on nine normal subjects, and $21 \%$ in nine diabetic subjects.

The day-to-day variation in the value given to insulin resistance assessed by any method is dependent on two factors: changes in the body's insulin resistance from day-to-day, and the precision of the method used. For an individual, insulin resistance is not at a constant level but varies according to factors, such as preceding exercise and food intake. The comparison of paired mean CIGMA profiles in the nine normal subjects, segregated by the day with the higher achieved insulin concentrations, showed how fasting glucose and insulin concentrations on the one hand, and stimulated concentrations on the other, varied similarly from day-today. This suggests that these patients were really more insulin resistant on the day of the higher achieved insulin level test, whether assessed by fasting or by stimulated glucose-insulin results.

$\beta$-cell function is also likely to vary from day-to-day, especially under the influence of diet [33]. This will similarly decrease the apparent precision of the CIGMA measure of $\beta$-cell function. The variation of insulin resistance is also likely to influence $\beta$-cell function and vice versa.

\section{Practical aspects}

In its most simple form, CIGMA entails a 60-min infusion of glucose with glucose and insulin assay of three plasma samples taken during the last $15 \mathrm{~min}$ to take into account the pulsatility of insulin secretion [22]. The insulin resistance and $\beta$-cell function are then read from a chart using the mean glucose and insulin levels. It is also possible to obtain estimates of $\beta$-cell function and insulin resistance from model assessment of basal plasma insulin and glucose concentrations $[5,8,34]$, but the re- 
sults are less precise than by CIGMA. Clamp techniques are widely used, but are extremely labour-intensive and, if a closed loop feedback system is used, require expensive equipment.

The CIGMA test has potential as a routine test for glucose tolerance and for assessing the pathophysiology of Type 2 diabetic patients, provided they do not have glycosuria during the test.

Acknowledgements. We are grateful to the Oxford Medical School Research Fund, the Charles Wolfson Charitable Trust and the Bayer Company for grants. We are indebted to Mrs. E. A. Harris and Mrs. E. G. Davies for technical and nursing assistance. The manuscript was expertly prepared by Mrs. H.Christian and Miss R.Church. Dr. D.R. Matthews is the Joan and Richard Doll Senior Research Fellow at Green College, and Dr. A. S. Rudenski has a MRC Training Fellowship.

\section{References}

1. Turner RC, Matthews DR (1984) Insulin secretion in Type I and Type II diabetes. Front Diabetes 4: 36-54

2. Reaven G, Bernstein R, Davies B, Olefsky JM (1976) Non-ketotic diabetes mellitus: insulin deficiency or insulin resistance? Am J Med 60: 80-88

3. Rizza RA, Mandarino LJ, Gerich JE (1981) Mechanism and significance of insulin resistance in non-insulin-dependent diabetes mellitus. Diabetes 30:990-995

4. Bergman RN, Phillips LS, Cobelli C (1981) Physiologic evaluation of factors controlling glucose tolerance in man. $\mathrm{J}$ Clin Invest 68 : $1456-1467$

5. Turner RC, Holman RR, Matthews D, Hockaday TDR, Peto J (1979) Insulin deficiency and insulin resistance interaction in diabetes: estimation of their relative contribution by feedback analysis from basal plasma insulin and glucose concentrations. Metabolism 28: 1086-1096

6. DeFronzo RA, Tobin JD, Andres R (1979) Glucose clamp technique: a method for quantifying insulin secretion and resistance. Am J Physiol 237: E214-223

7. Metropolitan Life Assurance Co (1959) Net weight standard for men and women. Stat Bull Metrop Life Found 40:1-4

8. Turner RC, Matthews DR, Holman RR, Peto J (1982) Relative contributions of insulin deficiency and insulin resistance in maturity-onset diabetes. Lancet 1: 596-598

9. Rowe GG, Maxwell GM, Castillo GA, Freeman DJ, Crumpton CW (1959) A study of cerebral blood flow and cerebral glucose metabolism before and after eating. $J$ Clin Invest 38: 2154-2158

10. Daniel PM, Love ER, Pratt OE (1975) Insulin stimulated entry of glucose into muscle in vivo as a major factor in the regulation of blood glucose. J Physiol 247: 273-288

11. Kolterman OG, Gray RS, Griffin J, Burstein P, Insel J, Scarlett JA, Olefsky JM (1981) Receptor and postreceptor defects contribute to the insulin resistance in non-insulin-dependent diabetes mellitus. J Clin Invest 68: 957-969

12. Ciaraldi TP, Kolterman OG, Olefsky JM (1981) Mechanism of the postreceptor defect in insulin action in human obesity. J Clin Invest $68: 875-880$

13. Bergman RN, Bucolo RJ (1974) Interaction of insulin and glucose in the control of hepatic glucose balance. Am J Physiol 227: 1314-1322

14. Felig P, Wahren J (1971) Influence of endogenous insulin secretion on splanchnic glucose and amino acid metabolism in man. $\mathrm{J}$ Clin Invest 50: 1702-1711

15. DeFronzo RA, Jacot E, Jequier E, Maeder E, Wahren J, Felber JP
(1981) The effect of insulin on the disposal of intravenous glucose. Diabetes 30: 1000-1007

16. Blackard WG, Nelson NC (1970) Portal and Peripheral vein immunoreactive insulin concentrations before and after glucose infusion. Diabetes 19:302-306

17. Turner RC, Grayburn JA, Newman GB, Nabarro JDN (1971) Measurement of insulin delivery rate in man. J Clin Endocrinol Metab 33: 279-286

18. Lerner RL, Porte D (1972) Acute and steady-state insulin responses to glucose in non-obese diabetic subjects. J Clin Invest 51 : $1624-1631$

19. Cerasi E, Luft R, Efendic S (1971) Decreased sensitivity of the pancreatic beta cells to glucose in prediabetic and diabetic subjects. A glucose dose-response study. Diabetes 21: 224-234

20. Turner RC, Harris E, Ounsted M, Ponsford C (1979) Two abnormalities of glucose-induced insulin secretion: dose-response characteristics and insulin sensitivity. Acta Endocrinol 92: 148-165

21. Grodsky GM (1972) A threshold distribution hypothesis for packet storage of insulin and its mathematical modelling. J Clin Invest 51: 2047-2059

22. Matthews DR, Lang DA, Burnett MA, Turner RC (1983) Control of pulsatile insulin secretion in man. Diabetologia 24: 231-237

23. Matthews DR, Hosker JP (1984) An unbiased, flexible computer programme for glucose clamping, with graphics and running statistics. Diabetologia 27: 308-309 A

24. Albano JDM, Ekins RP, Maritz G, Turner RC (1972) A sensitive, precise, radioimmunoassay of serum insulin relying on charcoal separation of bound and free hormone moities. Acta Endocrinol 70: 487-509

25. Harano Y, Ohgaku S, Hidaka H, Haneda K, Kikkaw R, Shigeta Y, Abe H (1977) Glucose, insulin and somatostatin infusion for the determination of insulin sensitivity. J Clin Endocrinol Metab 45: 1124-1127

26. Felig P, Wahren J, Hendler R, Brundin T (1974) Splanchnic glucose and amino acid metabolism in obesity. J Clin Invest 53 . $582-590$

27. DeFronzo RA, Ferrannini E, Hendler R, Felig P, Wahren J (1983) Regulation of splanchnic and peripheral glucose uptake by insulin and hyperglycaemic in man. Diabetes $32: 35-45$

28. World Health Organisation (1980) Expert Committee on Diabetes Mellitus. Technical Report Series 646, Geneva

29. Shen SW, Reaven GM, Farquhar JW (1970) Comparison of impedance to insulin-mediated glucose uptake in normal subjects and in subjects with latent diabetes. J Clin Invest 49:2151-2160

30. Scarlett JA, Gray RS, Griffin J, Olefsky JM, Kolterman OG (1982) Insulin treatment reverses the insulin resistance of type II diabetes mellitus. Diabetes 5:353-363

31. Ginsberg H, Rayfield EJ (1981) Effect of insulin therapy on insulin resistance in type II diabetic subjects. Diabetes 30: 739-745

32. Greenfield MS, Doberne L, Kraemer F, Tobey T, Reaven G (1981) Assessment of insulin resistance with the insulin suppression test and the euglycaemic clamp. Diabetes 30:387-392

33. Muller WA, Faloona GF, Unger RH (1971) The influence of antecedent diet upon glucagon and insulin secretion. New Engl J Med 285: 1450 1454

34. Matthews DR, Hosker JP, Rudenski A, Bown EG, Naylor BA, Treacher D, Turner RC (1985) Homeostasis model assessment: insulin resistance and $\beta$-cell function from fasting plasma glucose and insulin concentrations in man. Diabetologia: 412-419

Received: 15 December 1983

and in revised form: 31 May 1985

Dr. R. C. Turner

Diabetes Research Laboratories

Radcliffe Infirmary

Woodstock Road

Oxford OX2 6HE

UK 